\title{
Forensic Accounting Education: An Exploration of Level of Awareness in Developing Economies - Nigeria as a Case Study
}

\author{
Eme Joel Efiong \\ Faculty of Business and Law, De Montfort University \\ Leicester, UK \\ Tel: 44-777-420-3248Ｅ-mail: emetom@yahoo.com
}

$\begin{array}{ll}\text { Received: November 11, } 2011 & \text { Accepted: December 27, } 2011 \quad \text { Published: February 16, } 2012 \\ \text { doi:10.5539/ijbm.v7n4p26 } & \text { URL: http://dx.doi.org/10.5539/ijbm.v7n4p26 }\end{array}$

\begin{abstract}
Although there is a growing demand for fraud and forensic accounting globally, much of its advancements and adoption in the accounting curriculum in the universities are taking in the developed economies. Equally, empirical studies tend to be set mostly in the developed economies with little representation of the situation in the developing economies. Furthermore, existing empirical studies have focused exclusively on the views of academics and practitioners, in accessing the demand for forensic accounting. In this study we present fresh and distinctive evidence on the awareness of forensic accounting among accounting undergraduates in a developing economic setting, using Nigeria as a case study. We found that there is a very low level of awareness on forensic accounting among undergraduate students. We contend that adoption of forensic accounting into the universities accounting curriculum has a huge potential to enhance students skills and competencies and could be use as a veritable resources from which fraud could be mitigated. Our study has important policy implications.
\end{abstract}

Keywords: Fraud prevention, Fraud detection, Forensic accounting education, Nigeria

\section{Introduction}

This paper explores the level of awareness of forensic accounting among accounting students in a developing economy context, using Nigeria as a study. Accounting as a social science plays significant roles in the society. It serves not only as a legitimating device for the market economic system, but also as a form of social language and certainly a business language, through which meanings and implications are constructed by social actors in a society. However, accounting figures are heavily exposed to fraud due to their influence on numerous crucial decisions that affect various key social actors with far reaching implications. For example, accounting figures are sources of rewards for management, a basis for investors' decisions and a basis for the assessment of firm performance and grouping in the sense of profitable and none profitable firms. These numerous needs and interest makes accounting figures to be extremely susceptible to fraud.

Fraud in accounting has been discoursed along two main dimensions viz fraudulent financial reporting and misappropriation of firm resources. Fraudulent financial reporting refers to deliberate and calculated activities and attempts to misrepresent transactions in the financial statement in order to derive or take undue advantage. On the other hand misappropriation of assets refers to deliberate and calculated activities to take firms resources without authorization, this includes stealing etc.

Studies have suggested that the increase in the adoption of forensic accounting courses as part of the accounting curriculum in a growing number of universities is indicative of the demand for sets of competences and skills that are commensurate and sophisticated enough to confront the complexities that businesses faced with respect to growing threats arising from fraud. Furthermore, accounting education as a social and public good should reflect the identified needs of the society and especially of business where future graduate from these institutions would most probably work. Proponents of this line of argument contend that accounting students as members of the labour force should posses required skills (Mohamed and Lashine, 2003) to function in the work place. This also reinforces the argument that the educational institutions play major role in constructing, interpreting and reinforcing societal values through knowledge dissemination and transfer that takes place within them (Rezaee and Burton, 1997). Therefore societal ills could be confronted via increasing education on the causes and potential remedies to such problem. Similarly, fraud as a social problem could be confronted through education in the form of curricula development e,g introduction of courses that could provide further clarifications on the 
nature and dimensions of the problems and therefore a better understanding and construction of the problem which would be eminently useful in devising potential solution to the problem.

However, while fraud and forensic accounting modules or courses are being incorporated into the curriculum in many developed economies, this is not the case in developing economies. Despite the fact that anecdotal and evidence in the press suggest that these countries are in more dire need of these skills and competences. For example, The Daily Sun Newspaper of Thursday, December 23, 2010 has the following captions on financial fraud:

- 27.3b COJA fraud: Amos Adamu arrested (Pages 1 \& 54)

- Halliburton: $\$ 139 \mathrm{~m}$ trapped in foreign banks -AGF (Page 6)

- Party chairman docked over $12 \mathrm{~m}$ theft (Page 13)

- $\quad$ EFCC should be involved in recovering debt owed FAAN (Page 43)

Furthermore, while most other countries have been able to reduce the occurrence of financial fraud in both the private and public sectors, the menace is rather on the increase in Nigeria, despite the establishment of the Independent Corrupt Practices and Other Related Offences Commission (ICPC) and the Economic and Financial Crimes Commission (EFCC). Nigeria is still ranked very low by the Transparency International Corruption Index. The 2010 survey places Nigeria at the $134^{\text {th }}$ position out of 178 countries that were sampled (http://www.transparency.org/policy_research/surveys_indices/cpi/2010).

Inadequate emphasis on fraud deterrent practice and on education contributed to fraudulent activities in large and mid-size US companies (KPMG Peat Marwick Survey, 1994). It is the expectation of many groups for accountants to assume a more active role in guaranteeing a reasonable assurance with respect to reliable financial reporting, and detecting and preventing fraudulent financial activities.

According to the US General Accounting Office (GAO) (1996), there is now a strong emphasis on fraud prevention and detection during statutory audits. In fact the United States and international standards setters have increased the responsibility of auditors to consider the risks of fraud while conducting audits of financial statements. There is even a call for stronger forensic skills in those who perform these audits. This has been collaborated by Enyi (2009) who submits that all normal statutory audits should contain some elements of forensic enquiry as the evidence of fraudulent activities can be easily discovered if a thorough evaluation of the adequacy and compliance of the internal control mechanism is made. All these are aimed at fraud prevention and detection. But, this may not be achieved by an auditor without some understanding of forensic accounting methods. Hence, the need for forensic accounting education of which many countries have adopted.

Events of the recent years have contributed to the growing demand for forensic accounting profession. With the high prevalence of fraud in the society, the importance of forensic accounting training cannot be over-emphasized. Forensic accounting can be used to prevent, detect and respond to harm caused by fraud. Forensic accounting has the sole aim of unveiling fraudulent activities within and outside an organization. It is the application of financial skills and investigative mentality to resolved issues, conducted within the rules of evidence (Bologna and Lindquist, 1987). Crumbley (2003) summarizes it as the "application of laws of nature to the laws of man'. In general terms, forensic accounting involves reporting where fraud is established and the report is considered as evidence in the court of law. The engagements of forensic accounting techniques are usually geared towards finding where money went, how it got there and who was responsible.

Forensic accounting can teach students how to provide accounting analyses that are suitable for court, through the use of accounting, auditing and investigative skills. Kleyman (2006) believes that enrollment in forensic accounting course can show to students a different side of such a renowned discipline as accounting. Also, forensic accounting provides the practitioner with profound knowledge of both accounting and law. Such a professional will not only be able to investigate accounting issues, but will also be able to collect evidence, provide litigation support, as well as testify in court. This is a herculean task. However, forensic accounting is one of "the top 10 next hot jobs" (Bralove, 2004 in Kleyman 2006).

It is in view of the above submissions and endemic nature of fraud in Nigeria and the necessity of specialize skills to unveil such frauds that it becomes imperative to advocate for the introduction of forensic accounting techniques into the curriculum of the undergraduate programmes in accounting. Education is has a formative effect on the mind, character or physical ability of an individual through the dissemination of knowledge. Educational institutions provide the avenue through which the knowledge is disseminated. They provide the barometers to measure the potential for dissemination of new concepts and indeed its future development. Educational institutions can become an avenue for setting free a people from ignorance. This is because 
knowledge is easily passed through the students who are forming future values and ethos. Of course, students represent the future manpower potential of any country and should be empowered with knowledge. Hence, this paper examines the level of awareness of forensic accounting among accounting students in a number of universities in Nigeria. As would be seen from the literature review in the next section, forensic accounting education continues to receive high priority attention in curriculum development in developed countries. But this is certainly not the case with many developing nations, like Nigeria, yet fraudulent activities are common phenomena in the country. It was only very recently (May, 2010) that the first set of sixteen (16) graduates completed a forensic accounting certificate course that was developed by the Institute of Chartered Accountant of Nigeria (ICAN). They were also inducted into the Institute as forensic experts in a ceremony that could be described as a milestone, not only in the history of the Institute but that of the entire country at large. Also, most of the studies on forensic accounting education where carried out on academicians and practitioners. It is however, important to garner the views of student in this important discourse. Accounting students are part of the mechanisms through which curriculum change could be actualized. It should therefore be interesting to appreciate their views on this issue. This study seeks to fill the current void in the literature by examining the level of awareness of forensic accounting by accounting students in a number of universities in Nigeria.

The rest of the paper is structured as follows. Section 2 presents the literature review; this is followed in section 3 , which deals with the study methodology and data collection. Section 4 deals with results and findings and the study is concluded in section 5 where we provided suggestion for future studies and identify the limitations of the current study.

\section{Literature review}

The literature on forensic accounting and its adoption in accounting and finance curriculum is rather limited and they are US centric. However, our objective in this section was to highlight the core findings in the few relevant current studies rather than an extensive examination of tangential issues to forensic accounting and its adoption in accounting and finance curriculum, so as to serve as the basis to situate our own study.

Carnes and Gierlasinki (2001) have noted that inevitably, accountants are being held to higher standards in their ability to understand and find fraudulent activities within organizations. However, what is not so clear is whether accountants are receiving the kind of education that will help them in this task. This therefore led to calls for a change in the way accounting is taught. For example, Kullberg (1986) noted demand by some accounting firms in the US for curricular change and increased interaction between academia and practicing accountants in order to keep academic courses consistent with the challenges in the field as they are being faced by practitioners. Similarly, there is also another call for different perspective on the preparation for career in accounting (American Institute of Certified Public Accountants, AICPA, 1999).

Despite these demands, Rezaee and Burton (1997) and Gierlasinki et al. (1998) observed a very slow, if any, curricular change in accounting education. The reasons always given during surveys for this slow pace in change of accounting curricular include: not having enough room in the curricular to include additional training in fraud or forensic accounting, or /and, that the school must stick to the basics of intermediate, cost and audit accounting.

But it is now very clear that a lot have changed. For instance, forensic accounting is now very popular with students rating it 9.14 on a ten-point satisfaction scale in the US (Buckhoff and Schrader, 2000) and many other developed countries. This change may have been propelled by the fact that the Accounting Education Change Commission (AECC) in 1990 and the AICPA in 1998 have advanced the idea of 150-hours requirement for competency in the accounting profession (Doost, 1999) and by 2001, 48 states in the US had passed legislation to require 150 semester hours for accounting students and as a prerequisite for writing Certified Public Accountant (CPA) examination. This provided the needed impetus for the introduction of new courses, including forensic accounting, into the accounting curriculum.

Razaee and Burton (1997) examined the current average and future direction and the role of accounting education, using academicians and certified fraud examiner practitioners. The study, among others, concluded that the demand for forensic accounting education and practice will continue to increase and that forensic accounting education should be integrated into accounting curricular either as a separate course or as modules in accounting and auditing.

As regulators continue to increase the responsibility for auditors to detect fraudulent financial statements, the demand for forensic accounting educations was further highlighted in Carnes and Gierlansinki (2001). The authors examined the mismatch between the supply of and demand for auditors with forensic accounting skills. They noted that the universities have been slow in responding to this demand, particularly in designing courses 
to improve the students' understanding of fraud or their abilities to detect it. But there is also a great improvement in this direction.

Research has shown that a number of Universities, particularly in the US are already offering forensic accounting courses while some are even introducing full academic programmes in the area. Kleyman (2006) reviews some examples of these institutions and the programmes they offer in forensic accounting. For example, he notes that California State University, Northbridge has been teaching forensic accounting course as part of its regular accounting programme and the result has been quite impressive. In view of the above success, Sodders (2005) submits that it may lead to "a post-bachelor's degree certificate in forensic accounting" at the University.

Villa Julie College in Maryland, United States, has been teaching forensic accounting for some years now. She initiated a master's programme in forensic studies in response to the corporate financial scandal. Six general courses in forensic studies were taken by the students who had an option of specializing in one of the three fields: accounting, information technology and law (Kleyman, 2006). Other accredited institutions that teaches forensic accounting in the US include, The University of Texas at Austin, The University of Nebraska at Lincoln, The University of Denver, Brigham Young University, Regis University, the West Virginia University, Louisiana State University, and others. Several Universities in the United Kingdom, including De Montfort University, are also involved in teaching forensic accounting.

\section{Methodology}

Previous studies have focused exclusively on academic and practitioners as the sources of data for their investigation, yet the views of the students who are the recipients of the skills taught in the educational institutions are equally very important. Unlike previous studies we focus on the level of awareness of forensic accounting by the students. Data collection instrument for the study was through questionnaire. The purpose of the survey was clearly stated to enable the respondents see the need to give accurate answers to the questions in the questionnaire. The letter also assured the respondents of the confidentiality of their responses. To enhance the response rate and understanding the expected respondents, the questions were brief and limited. This enabled us to focus on key objectives of the study. We therefore left out personal data of the respondents. This also potentially reduces respondents' boredom since they do not have to spend a lot of time answering the questions. Another possible advantage on keeping the questions brief and limited is that respondents are more likely to answer the question out of interest rather than just filling in the questionnaire to satisfy researcher. Copies of the questionnaire were administered using the face-to-face approach through three (3) trained research assistants.

Third and final (fourth) year undergraduate accounting students from three Nigeria universities were chosen as the population of study. The choice of the third and final year students was based on the readiness and level of knowledge of the respondents. Firstly year three and final year students are more likely to have higher appreciation of the relationship between their course of study and the reality of employments than first and second year students. Secondly, having being through their first and second years of studies, these sets of students are more likely to have greater exposures to developments in accounting and curriculum issues than students in their first or second years of study in the university. Also, these sets of students must have gone through the introductory part of their curriculum and now ready to take on the more advanced courses in accounting. Thus third and final years accounting students from three main universities in the south eastern part of Nigeria were involved in the study. These are University of Calabar, Cross River University of Technology and University of Uyo.

These universities were chosen a number of reasons. Firstly, the researcher is an indigene of this part of the country and therefore has sufficient familiarity and knowledge of the culture and values of the area which is important in the design of the survey instrument. Secondly, in order to enhance the validity of the study, the researcher chose two federal universities and the other state university. It is generally perceived that federal universities are better resourced than their state counterpart. This resource advantage could therefore affect their curriculum content in term of the teaching of forensic accounting. Lastly, while it would have been preferred to enhance the scope of the study by examining the level of awareness across all the over 50 universities in the country, this will require massive financial support which is not available to the researcher. Table 1 below shows the sample population and the sample size used in the study. Sampling was random in that it was neither convenient nor purposeful. To enhance representation, the researcher used $30 \%$ sample size across all the sample population.

The survey instrument has six questions. The first question was a screening question that distinguishes between the years of study. Respondent were asked to identify if they are in year 3 or 4 . And quickly, the second question asked if respondents are aware of the existence of forensic accounting or not. Respondents that answered yes 
were asked to identify their source of information about forensic accounting. Question four was to further reestablish the findings in question 2 by asking if respondents know what forensic accounting is about. The researcher appreciates that it is quite possible for students to be aware of forensic accounting but not know what it is about. However, is more likely that students that are aware of the course would have some knowledge about it. In question 5, we introduced a likert scale to decipher whether students who know about forensic accounting would expect it to impact on their education, and lastly we asked if the respondents expect the introduction of forensic accounting to impact on the fight against fraud in the country. The next section presents our results and their discussions.

\section{Results and Discussion}

The results of the survey are presented in tables 2-6. Table 2 shows the result of the awareness of the existence of forensic accounting. The table reveals that out the 168 respondents, 90 (53.57 percent) claimed awareness of the existence of forensic accounting while 78 (46.43 percent) were not aware of such.

Table 3 presents the first source of information on the existence of forensic accounting by the respondents who claimed "yes" in table 2.

Out of a total of 90 respondents, 11 (22.22 percent), first heard of forensic accounting in the classroom. A total of 9 respondents (10 percent) read from textbooks and journals, 33 respondents (36.66 percent) were from the internet while 14 of them (15.56 percent) got their first knowledge of forensic accounting from the print media. Similarly, 14 respondents (15.56 percent first heard from the radio and television while 9 respondents (10 percent) first got the information from other sources.

Table 4 reveals knowledge of forensic accounting techniques by the undergraduates. The result is quite revealing. None of the respondents ( 0.00 percent) claimed any knowledge of forensic accounting techniques. This is a very sad situation in Country that is being ravaged by fraud.

The result of the respondents' position on whether knowledge of forensic accounting would make positive impact on the undergraduate accountant during training (Table 5) shows that 65 (72.22 percent) strongly agreed, 21 (23.33 percent) simply agreed and 4 (4.45 percent) were indifferent. None of the respondents disagreed nor strongly disagreed with the position. But this impact has been eluding the undergraduates in Nigerian Universities.

Knowledge of forensic accounting techniques by accountant and auditors will certainly make some positive impact in the nation's fight against corruption. This was also the view of most of the respondents (table 6). This agrees with the result on table 5 .

The typical courses offered by most Departments of Accounting in Nigerian universities are shown in table 7.

This table shows that no courses are offered in the area of fraud detection or forensic accounting. The development of the manpower here does not reflect the demand at the time. But in most other countries, like the United States of America and United Kingdom, the development and training of manpower in the Universities and other Colleges has always been tailored to the need and for solving the problems at hand. For example, Kleyman (2006) notes that, "it is typical for American society to transform a demand for a profession into a course offering in the university". This could be seen to be in line with the idea of demand influencing supply. Hence, forensic accounting courses are studied in many universities in the United States.

But this is not the case with Nigeria! With over sixty four (64) universities offering accounting majors or accounting and finance in the Country (Joint Admissions and Matriculation Board Brochure, 2010), none is taking courses in forensic accounting. Why is the Nigeria's case different?

Recently, the National Universities Commission has made it mandatory for all undergraduates in Nigerian Universities to undertake a course titled: entrepreneurial development. This is to make the Nigerian graduate to be self reliant in the midst of high level unemployment in the labour market. If fraud in considered as a serious problem, a mandatory training (at least at the general knowledge level) should be included in the curriculum for the training of undergraduate accountants.

\section{Conclusion}

The place for forensic accounting education in Nigeria cannot be over-emphasized. This is in view of the ravaging nature of fraud on the economy of the Country. Forensic accounting can be used to prevent, detect and respond to harm caused by fraud. The lack of formal training schools in forensic accounting techniques has contributed to the high rate of financial fraud and other fraud related activities in Nigeria. Presently, there is no university in Nigeria that is offering forensic accounting courses to either her undergraduate or post-graduate 
students. This is at variance with what is obtained in other countries like, the United States of America and United Kingdom. This research has shown that forensic accounting education would go a long way in helping the country in her fight against corruption. It is therefore recommended that forensic accounting techniques should constitute an aspect of the curriculum for the training of undergraduate accountants in Nigerian universities. Also, specialization in forensic accounting at the post-graduate level should be encouraged. Furthermore, the Institute of Chartered Accountants of Nigeria and other regulating bodies should include forensic accounting in the curriculum of their professional examination. This is to ensure that all hands is on deck to reduce, if not, to put an end to financial frauds in the country.

\section{References}

Academic Programme Handbook (2010). Department of Accounting, University of Calabar.

American Institute of Certified Public Accountants (1999). Education requirement for entry into accounting profession. New York: AICPA.

Bologna, G. J., \& Lindquist, R. J. (1987). Fraud Auditing and Forensic Accounting: New Tools and Techniques. New Jersey: Wiley Publishers, (Chapter 3).

Buckhoff, T., \& Schrader, R. (2000). The teaching of forensic accounting in the United States. Journal of forensic accounting. 1(1), 135-146.

Carnes, K. C., \& Gierlasinski, N. J. (2001). Forensic accounting skills: will supply finally catch up to demand. Managerial Auditing Journal, 16(6), 378-382. http://dx.doi.org/10.1108/02686900110395514

Crumbley, D. L. (2003). What is Forensic Accounting?. [Online] Available: www.edwardspub.com

Doost, R. K. (1999). The missing links in accounting education. Managerial Auditing Journal, 14(3), 93-114. http://dx.doi.org/10.1108/02686909910259077

Enyi, E. P. (2008). Detecting Causes of Variances in Operational Outputs of Manufacturing Organization: A Forensic accounting Investigation Approach. [Online] Available: http://ssrn.com/abstract $=1144783$

General Accounting Office (1996). The accounting profession major issues: progress and concerns. New York: GAO.

Gierlasinski, N., Carnes, K., \& Fuhriman, R. (1998). Teaching fraud awareness to students. Proceedings of the American Accounting association Western Regional Meeting, AAA, New York. [Online] Available: http://www.transparency.org/policy_research/surveys_indices/cpi/2010

Jeremiah, M. (2006). Nigerian Dwindling Economy. Journal Business Research, 11, $26-30$.

Joint Admissions and Matriculation Board (JAMB) (2010). Unified tertiary matriculation examination brochure. [Online] Available: http://www.jambutme.com/search/index.php

Kleyman, Y. (2006). A course in forensic accounting. Honors College Theses, 40. [Online] Available: http://digitalcommons.pace.edu/honorscollege_theses/40

KPMG Peat Marwick. (1994). The US fraud survey. New York: KPMG Peat Marwick.

Kullberg. (1986). Perspectives on education: capabilities for success in the accounting profession (The white paper). New York: Big eight accounting firms.

Mackeičius, J., \& Kazlauskienė, L. (2009). The Fraud Tree and its Investigation in Audit. Ekonomika, 85, 90-101.

Nwankwo, G. O. (1991). Bank Management: Principles and Practice. Lagos: Malthouse Press.

Nwaze, C. (2008). Fraud and anti-fraud challenges in contemporary Nigerian banking. Zenith Economic Quarterly, 3(1), 3-5.

Rezaee, Z., \& Burton, E. J. (1997). Forensic accounting education: insights from academicians and certified fraud examiner practitioners. Managerial Auditing Journal, 12 (9), 479-489. http://dx.doi.org/10.1108/02686909710185206

Sodders, L. (2005). New forensic field offered: accountancy specialty at California State in high demand, especially with FBI. The Daily News of Los Angeles, Lexis-Nexis Pace University.

The Daily Sun Newspaper. [Online] Available: www.sunnewsonline.com (December 23, 2010) 
Table 1. The population and sample size for the study

\begin{tabular}{|l|c|c|}
\hline Institution & $\begin{array}{c}\text { Sample } \\
\text { population }\end{array}$ & $\begin{array}{c}\text { Sample size (30 per cent } \\
\text { of the population }\end{array}$ \\
\hline University of Calabar (UNICAL) & 207 & 62 \\
Cross River University of Technology (CRUTECH) & 163 & 59 \\
University of Uyo (UNIUYO) & 190 & 168 \\
\hline Total & 560 & 57 \\
\hline
\end{tabular}

Table 2. Awareness of the existence of forensic accounting

\begin{tabular}{|l|c|c|c|c|c|c|}
\hline \multirow{2}{*}{ INSTITUTION } & \multicolumn{2}{|c|}{ YES } & \multicolumn{2}{|c|}{ NO } & \multicolumn{2}{c|}{ TOTAL } \\
\cline { 2 - 8 } & NO. & $\%$ & NO. & $\%$ & NO. & $\%$ \\
\hline University of Calabar (UNICAL) & 39 & 62.90 & 23 & 37.10 & 62 & 100 \\
Cross River University of Technology (CRUTECH) & 20 & 40.82 & 29 & 59.18 & 49 & 100 \\
University of Uyo (UNIUYO) & 31 & 54.39 & 26 & 45.61 & 57 & 100 \\
\hline TOTAL & 90 & 53.57 & 78 & 46.43 & 168 & 100 \\
\hline
\end{tabular}

Table 3. First source of information on the existence of forensic accounting

\begin{tabular}{|c|c|c|c|c|c|c|c|c|c|c|c|c|c|}
\hline \multirow[t]{2}{*}{ Institution } & \multicolumn{2}{|c|}{ Classroom } & \multicolumn{2}{|c|}{$\begin{array}{c}\text { Textbooks/ } \\
\text { Journals }\end{array}$} & \multicolumn{2}{|c|}{ Internet } & \multicolumn{2}{|c|}{ Print media } & \multicolumn{2}{|c|}{$\begin{array}{c}\text { Radio/ } \\
\text { TV }\end{array}$} & \multicolumn{2}{|c|}{ Others } & \multirow[t]{2}{*}{$\begin{array}{l}\text { Total } \\
\text { No. }\end{array}$} \\
\hline & No. & $\%$ & No. & $\%$ & No. & $\%$ & No. & $\%$ & No. & $\%$ & No. & $\%$ & \\
\hline UNICAL & 6 & 15.38 & 3 & 7.69 & 16 & 41.03 & 4 & 10.26 & 5 & 12.82 & 5 & 12.82 & 39 \\
\hline CRUTECH & 1 & 5.00 & 4 & 20.00 & 6 & 30.00 & 3 & 15.00 & 4 & 20.00 & 2 & 10.00 & 20 \\
\hline UNIUYO & 4 & 12.90 & 2 & 6.45 & 11 & 35.48 & 7 & 22.58 & 5 & 16.13 & 2 & 6.45 & 31 \\
\hline TOTAL & 11 & 12.22 & 9 & 10 & 33 & 36.66 & 14 & 15.56 & 14 & 15.56 & 9 & 10 & 90 \\
\hline
\end{tabular}


Table 4. Knowledge of forensic accounting techniques

\begin{tabular}{|l|c|c|c|c|c|c|}
\hline \multirow{2}{*}{ Institution } & \multicolumn{2}{|c|}{ Yes } & \multicolumn{2}{c|}{ No } & \multicolumn{2}{c|}{ Total } \\
\cline { 2 - 7 } & No. & $\%$ & No. & $\%$ & No. & $\%$ \\
\hline UNICAL & 0 & 0.00 & 39 & 100 & 39 & 100 \\
CRUTECH & 0 & 0.00 & 20 & 100 & 20 & 100 \\
UNIUYO & 0 & 0.00 & 31 & 100 & 31 & 100 \\
\hline TOTAL & 0 & 0.00 & 90 & 100 & 90 & 100 \\
\hline
\end{tabular}

Table 5. Knowledge of forensic accounting would make some positive impact on the undergraduate accountant during training

\begin{tabular}{|c|c|c|c|c|c|c|c|c|c|c|c|c|}
\hline Institution & \multicolumn{2}{|c|}{$\begin{array}{c}\text { Strongly } \\
\text { agree(SA) }\end{array}$} & \multicolumn{2}{|c|}{ Agree(A) } & \multicolumn{2}{|c|}{ Indifferent(I) } & \multicolumn{2}{|c|}{ Disagree(D) } & \multicolumn{2}{|c|}{$\begin{array}{c}\text { Strongly } \\
\text { disagree(SD) }\end{array}$} & \multicolumn{2}{|c|}{ Total } \\
\cline { 2 - 14 } & No. & $\%$ & No. & $\%$ & No. & $\%$ & No. & $\%$ & No. & $\%$ & No. & $\%$ \\
\hline UNICAL & 26 & 66.67 & 10 & 25.64 & 3 & 7.69 & 0 & 0.00 & 0 & 0.00 & 39 & 100 \\
CRUTECH & 16 & 80.00 & 4 & 20.00 & 0 & 0.00 & 0 & 0.00 & 0 & 0.00 & 20 & 100 \\
UNIUYO & 23 & 74.19 & 7 & 22.58 & 1 & 3.23 & 0 & 0.00 & 0 & 0.00 & 31 & 100 \\
\hline TOTAL & 65 & 72.22 & 21 & 23.33 & 4 & 4.45 & 0 & 0.00 & 0 & 0.00 & 90 & 100 \\
\hline
\end{tabular}

Table 6. Knowledge of forensic accounting by accountants and auditors will make some positive impact on the nation's fight against corruption

\begin{tabular}{|c|c|c|c|c|c|c|c|c|c|c|c|c|}
\hline \multirow[t]{2}{*}{ Institution } & \multicolumn{2}{|c|}{$\begin{array}{c}\text { Strongly } \\
\text { agree (SA) }\end{array}$} & \multicolumn{2}{|c|}{ Agree (A) } & \multicolumn{2}{|c|}{ Indifferent (I) } & \multicolumn{2}{|c|}{ Disagree(D) } & \multicolumn{2}{|c|}{$\begin{array}{c}\text { Strongly } \\
\text { disagree (SD) }\end{array}$} & \multicolumn{2}{|c|}{ Total } \\
\hline & No. & $\%$ & No. & $\%$ & No. & $\%$ & No. & $\%$ & No. & $\%$ & No. & $\%$ \\
\hline UNICAL & 26 & 66.67 & 10 & 25.64 & 3 & 7.69 & 0 & 0.00 & 0 & 0.00 & 39 & 100 \\
\hline CRUTECH & 16 & 80.00 & 4 & 20.00 & 0 & 0.00 & 0 & 0.00 & 0 & 0.00 & 20 & 100 \\
\hline UNIUYO & 23 & 74.19 & 7 & 22.58 & 1 & 3.23 & 0 & 0.00 & 0 & 0.00 & 31 & 100 \\
\hline TOTAL & 65 & & 21 & & 4 & & 0 & & 0 & & 90 & \\
\hline
\end{tabular}


Table 7. Academic programme for a typical accounting course

\begin{tabular}{|c|c|c|c|}
\hline Year of study & Semester & Course No. & Course Title \\
\hline \multirow[t]{2}{*}{1} & $1^{\text {st }}$ & $\begin{array}{l}\text { GSS } 1101 \\
\text { GSS } 1121 \\
\text { GSS } 1111 \\
\text { MTH } 1011 \\
\text { MSS } 1401 \\
\text { ECS } 1301 \\
\text { ACC } 1301 \\
\end{array}$ & $\begin{array}{l}\text { Use of English I } \\
\text { Philosophy and Logic } \\
\text { Citizenship Education } \\
\text { Mathematics for Social Sciences I } \\
\text { Introduction to Business } \\
\text { Introduction to Macro-economics I } \\
\text { Principles of Accounts } \\
\end{array}$ \\
\hline & $2^{\text {nd }}$ & $\begin{array}{l}\text { GSS } 1102 \\
\text { GSS } 1132 \\
\text { MTH } 1022 \\
\text { BAF } 1202 \\
\text { BAF } 1302 \\
\text { ECS } 1202 \\
\text { MSS } 1402 \\
\end{array}$ & $\begin{array}{l}\text { Use of English II } \\
\text { History and Philosophy of Science } \\
\text { Mathematics for Social Sciences II } \\
\text { Principle of Finance } \\
\text { Introduction to Money and Banking } \\
\text { Introduction to Macro-economics II } \\
\text { Nigeria Business Environment }\end{array}$ \\
\hline \multirow[t]{2}{*}{2} & $1^{\text {st }}$ & $\begin{array}{l}\text { GSS } 2111 \\
\text { ACC } 2201 \\
\text { ACC } 2101 \\
\text { ACC } 2121 \\
\text { ECS } 2201 \\
\text { MSS } 2501 \\
\text { MSS } 2401 \\
\end{array}$ & $\begin{array}{l}\text { Introduction to Computer } \\
\text { Business Statistics I } \\
\text { Introduction to Financial Accounting I } \\
\text { Introduction to Cost \& Management Accounting I } \\
\text { Microeconomic Theory } \\
\text { Principles of Marketing } \\
\text { Principles of Management }\end{array}$ \\
\hline & $2^{\text {nd }}$ & $\begin{array}{l}\text { GSS } 2112 \\
\text { ACC } 2212 \\
\text { ACC } 2202 \\
\text { ACC } 2102 \\
\text { ACC } 2122 \\
\text { ECS } 2302\end{array}$ & $\begin{array}{l}\text { Computer Application } \\
\text { Business Mathematics } \\
\text { Business Statistics II } \\
\text { Introduction to Financial Accounting II } \\
\text { Introduction to Cost \& Management Accounting II } \\
\text { Macroeconomic Theory }\end{array}$ \\
\hline \multirow[t]{2}{*}{3} & $1^{\text {st }}$ & $\begin{array}{l}\text { ACC } 3101 \\
\text { ACC } 3201 \\
\text { ACC } 3301 \\
\text { ACC } 3311 \\
\text { ACC } 3401 \\
\text { ACC } 3411 \\
\text { ACC } 3501\end{array}$ & $\begin{array}{l}\text { Intermediate Financial Accounting I } \\
\text { Cost Accounting } \\
\text { Quantitative Techniques in Accounting } \\
\text { Business Law I } \\
\text { Taxation I } \\
\text { Accounting Theory / Seminar } \\
\text { Management Accounting I }\end{array}$ \\
\hline & $2^{\text {nd }}$ & $\begin{array}{l}\text { ACC } 3102 \\
\text { ACC } 3202 \\
\text { ACC } 3312 \\
\text { ACC } 3402 \\
\text { ACC } 3502 \\
\text { POS } 1102 \\
\end{array}$ & $\begin{array}{l}\text { Intermediate Financial Accounting II } \\
\text { Research Methods in Accounting } \\
\text { Business Law II } \\
\text { Taxation II } \\
\text { Management Accounting II } \\
\text { Elements of Government }\end{array}$ \\
\hline \multirow[t]{2}{*}{4} & $1^{\text {st }}$ & $\begin{array}{l}\text { ACC } 4311 \\
\text { ACC } 4321 \\
\text { ACC } 4701 \\
\text { ACC } 4900 \\
\text { MSS } 4461 \\
\text { BAF } 4201 \\
\text { BAF } 4241 \\
\end{array}$ & $\begin{array}{l}\text { Advanced Financial Accounting I } \\
\text { Auditing and investigation I } \\
\text { Research Project I } \\
\text { Business Policy and Strategy I } \\
\text { Financial Management } \\
\text { Public Finance } \\
\end{array}$ \\
\hline & $2^{\text {nd }}$ & $\begin{array}{l}\text { ACC } 4302 \\
\text { ACC } 4312 \\
\text { ACC } 4322 \\
\text { ACC } 4342 \\
\text { ACC } 4742 \\
\text { ACC } 4900 \\
\text { MSS } 4462 \\
\end{array}$ & $\begin{array}{l}\text { Entrepreneurial Development } \\
\text { Advanced Financial Accounting II } \\
\text { Auditing and Investigation II } \\
\text { Public Sector Accounting } \\
\text { Management Information System } \\
\text { Research Project II } \\
\text { Business Policy and Strategy II } \\
\end{array}$ \\
\hline
\end{tabular}

Source: Academic Programme Handbook, Department of Accounting, University of Calabar, 2010. 